Introduction i ha Pathologie du Système Nervecx. F. J. Corlet. Um volume com 368 páginas e 54 ilustraçð̃es. G. Doin et Cie., Paris, 1950. Preço: $1.300 \mathrm{fr}$.

Caracteriza êste livro o fato de abordar a neuropatologia sob o ponto de vista dos distúrbios funcionais e não com critério exclusivamente nosológico. Assim, podemos ler um interessante capítulo sôbre a "fisiopatologia da preensão". Partindo de bases anátomo-funcionais inteiramente atualizadas, o autor chega à fisiopatologia e $\grave{A}$ terapêutica.

Começa por estudar o neurònio; depois, a propósito dos reflexos e automatismos, trata das mielites. No córtex cerebral, descreve as localizações motoras (epilepsia focal), a motricidade voluntária (hemiplegias), o sistema extrapiramidal (o parkinsonismo), os movimentos anormais e os estados convulsivos (epilepsia), o tronco do encéfalo (paralisias oculomotoras, faríngeas e laríngeas, a siringobulbia). Passando depois ao estudo da sensibilidade, trata das alucinações, hemianestesias, siringomielia, tabes, desordens sensoriais, terminando pelo estudo das agnosias. Seguen-se capítulos destinados aos distúrbios de funções especificamente humanas (a atitude erecta, a marcha, as emoções, a linguagem). O volume é encerrado com o estudo dos tumores intracranianos e das meningites.

Trata-se, evidentemente, de um livro incompleto, deixando de lado numerosas e importantes entidades mórbidas; entretanto, pela originalidade com que a matéria é exposta e pelo agrado com que é lido, está certamente destinado a despertar o interêsse dos que se iniciam no citudo da neurologia clínica.

\title{
H. Canelas.
}

